\title{
Serenade to a Cat: An lconography of Laughter
}

\section{Minerva Keltanen}

doi.org/10.23995/tht.112381

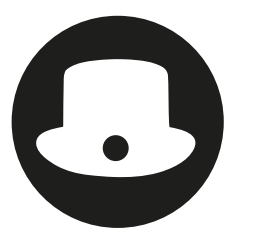

Lectio praecursoria: Minerva Keltanen's art history dissertation "Serenade to a Cat: An Iconography of Laughter" was examined at the University of Helsinki on the 17th of November 2020. The opponent was Dr. Sheila McTighe (The Courtauld Institute of Art) and the custos was Prof. Ville Lukkarinen (University of Helsinki). helda.helsinki.fi/handle/10138/320606

Keywords: Laughter, humor, comic, genre art, cat, peasants, carnivals, charivari, commedia dell'arte, blasphemy, pitture ridicole, early modern, sixteenth century, seventeenth century, Lombardy, Dutch art, Flemish art, French art, Italian art, attribution, provenance, art market, copy. 


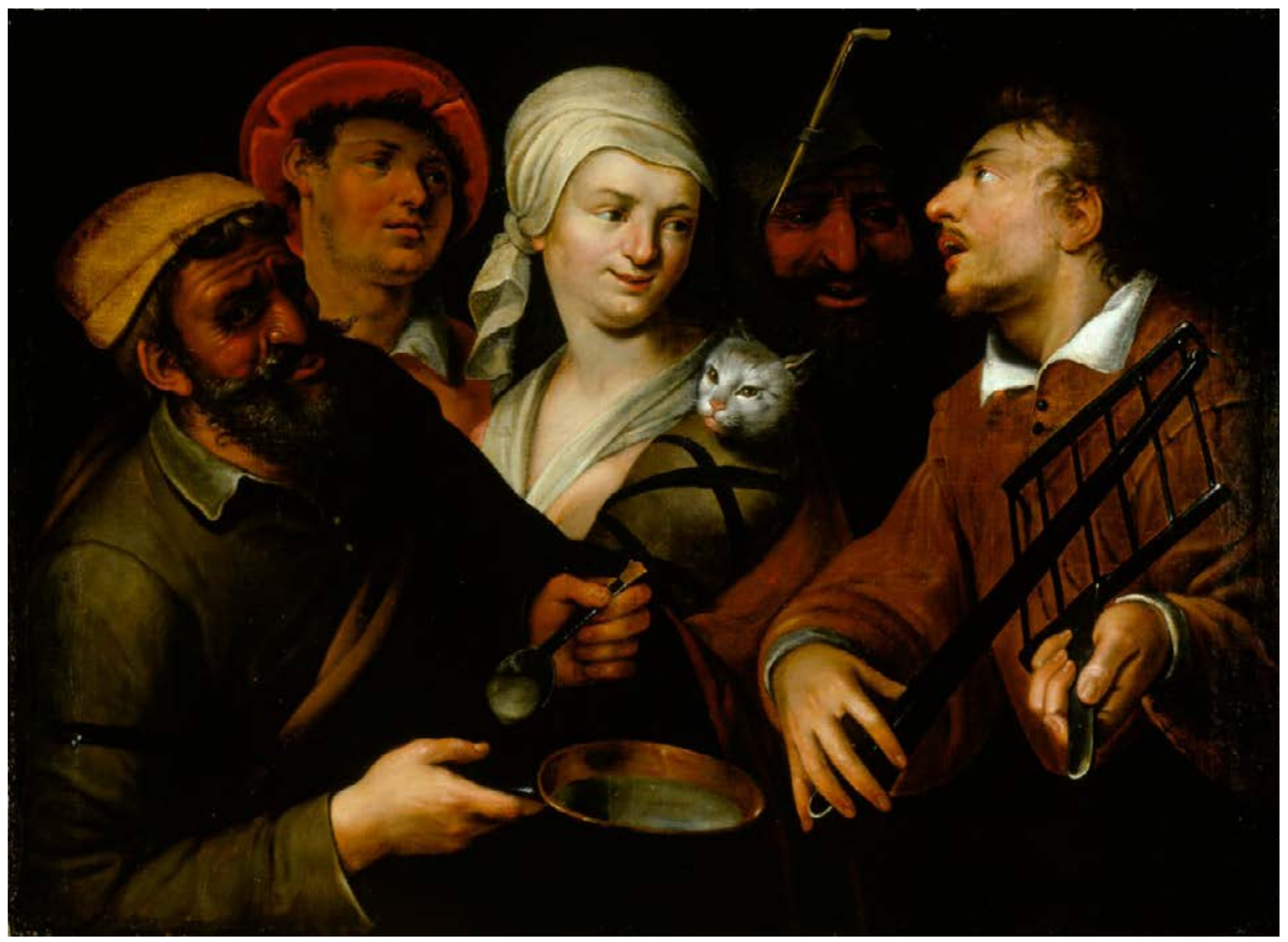

Figure 1. Serenade to a Cat by Unknown, oil on canvas, 75.5. x $103 \mathrm{~cm}$, in the collection of the Sinebrychoff Art Museum/ Finnish National Gallery, inv. no. A I 344. Photo: Jaakko Lukumaa.

There is a common saying that You should never explain the joke. However, explaining the subject and reason why five persons are in a merry mood and feeding a swaddled cat, playing a gridiron like a violin in a group of images which I generally call Serenade to a Cat, is one of the topics in my dissertation.

My interest in the subject of the present study dates back a good 20 years, when I was holding the post of Chief Curator at the Sinebrychoff Art Museum in Helsinki. The enigmatic painting called Serenade to a Cat in the museum's storage room appeared to be a complete riddle and made me interested in such questions as what tools do you have for attributing a painting to some artist, resolving the date, provenance, and subject matter, if you have none or hardly any information to start with?

This challenge, as well as understatement of humor, comic genre, and marginal subject matters in the discipline of art history, are some of the reasons why Serenade to a Cat attracted me. I started to trace and collect images and information about similar paintings from auction and fine art sellers' catalogues, museum catalogues, collections, and image archives abroad, and I found altogether eight oil paintings and two engravings of the same subject, which proves on the one hand the popularity of the theme and on the other the diffusion of the theme. Finding the engravings was important, as there was a French verse written on them and also the name 
Figure 2. L'Éducation du matou is signed le Blond excud. avec privilege, engraving, $20.3 \times 30.1 \mathrm{~cm}$, in the collection of the author, the other known version in the Bibliothèque nationale de France. Photo: Minerva Keltanen.

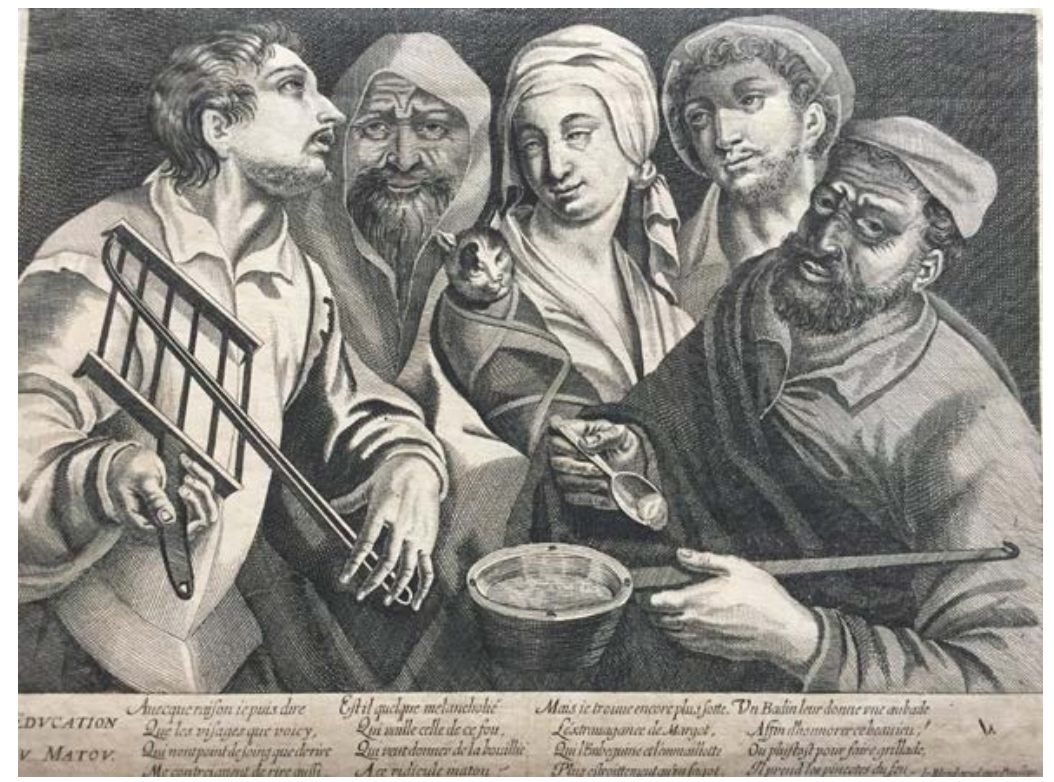

of the publisher, Jean LeBlond. The prints are titled L'Éducation du matou (The Education of a Tomcat), which could be even the original preserved title for the theme which I generally call here Serenade to a Cat, after the Helsinki painting. Teaching or giving a lesson to a cat is very unlikely to happen, because of their independent nature. Therefore, the whole idea is ridiculous, and the title gives a satirical tone to the subject.

Through the documentation of all the Serenade to a Cat images which I have found, the aim of my dissertation is twofold. First, it explores the Serenade to a Cat images and the relationship between art and humor by setting the theme in its historical and social context. Second, it tries to resolve the author, date, and provenance by taking the painting of Helsinki as an example for a case study. In the assessment of attribution, also the stylistic and compositional elements of the painting, in addition to the history of costumes, are taken into consideration. The method of my investigation is a combination of iconography, comparison of other closely related works, and historical contextualization. Because I have had no original sources available, I had to rely on earlier literature and scientific articles in addition to technical examination of materials gathered from a case study. I will now explain shortly my mode of approach before presenting the results.

\section{Iconography}

Erwin Panofsky, who was the most eminent representative of the iconographic-iconological method, presented the concept of "disguised symbolism." ${ }^{\text {"B }}$ By disguised or concealed symbolism he implied that many things in paintings carry hidden meanings, and one has to be able to read the coded symbols in order to resolve the meaning of the painting.

One of my assumptions in this study is that the Serenade to a Cat theme does contain more than meets the eye, and its visual motifs carry some meaning. As a consequence, the composition on the picture plane signifies the importance of the particular visual motif and symbol, the cat. Alternatively, if this is not the case, the images imply a narrative in which the figure of cat is central. Therefore, I argue that the cat is the key figure in interpreting the enigma of the Serenade to a Cat theme and other comparative paintings,

1 E. Panofsky, "Jan van Eyck's Arnolfini Portrait," The Burlington Magazine, vol. 64 (1934): 117-127. 
Figure 3. An example of the Lombard group by Giovanni Paolo Lomazzo, oil on panel, $43.2 \times 61 \mathrm{~cm}$, sold at Sotheby's New York 26.02.2012, lot 17. Photo: Sotheby's.

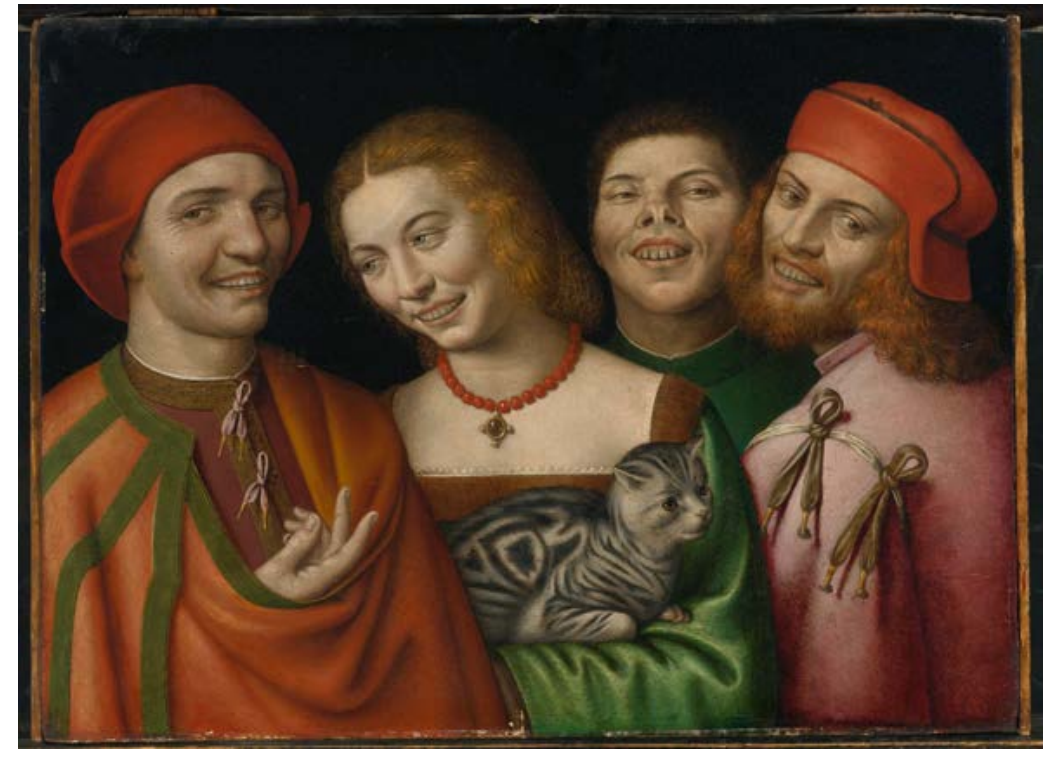

and that the cat most obviously fulfils a symbolic function, which we have to decode.

However, our difficulty lies in determining that our interpretation of an image from the past is a correct one because of the rupture between our own age and the period of the pictures we observe. In addition, there is the apparent danger of over-intellectualizing the analysis of an artwork, that is, the researcher reading hidden cryptic meanings that do not originally exist in the work.

\section{Comic}

"The iconography of laughter" in the title of this study refers to what moves the viewer to laugh when beholding this group of paintings, and how the Serenade to a Cat images construct or express that they belong to the world of the risible.

Aristotle's and Cicero's view that the deformed is a source of laughter came to form the principal basis of Renaissance theories of the risible. ${ }^{2}$ Ugliness and disharmony of proportions, which aside from being ridiculous, were also considered signs of moral depravity. A laughing face is one of

2 Aristotle, Poetica, 5 (1449a); Cic. De orat. 2.236-239, 2.66 . the strongest indicators that a work of art belongs to the comic category. Laughter was mainly reserved for the lower social classes, the devil, and Death in visual arts before the sixteenth century. Afterwards, it was related to foolishness and stupidity, the unbridled behavior of peasants and the other lower social classes.

The strong amalgamation of the comic content and genre painting goes back to ancient comparisons between comedy and the visual arts. Tragedy writers and history painters present people as larger than life, as great heroes, whereas comic writers and genre painters represent people as they are, or even worse, as fools, as they show the human being's every vice and virtue. The passions (or movements of soul) and expressions of emotions were important for the development of comic imagery, and in this they were associated with comedy theater and comic literature as well. The motifs of laughter or the comic permeated visual art both in Italy and in the North with the rise of genre painting and commedia dell'arte at the end of the sixteenth century.

However, comic paintings were not endorsed by the Catholic Church. They were condemned on moral grounds, as the comic art was often related to immoral subjects. In his Discorso intorno alle immagini (1582), the Bolognese Cardinal Gab- 


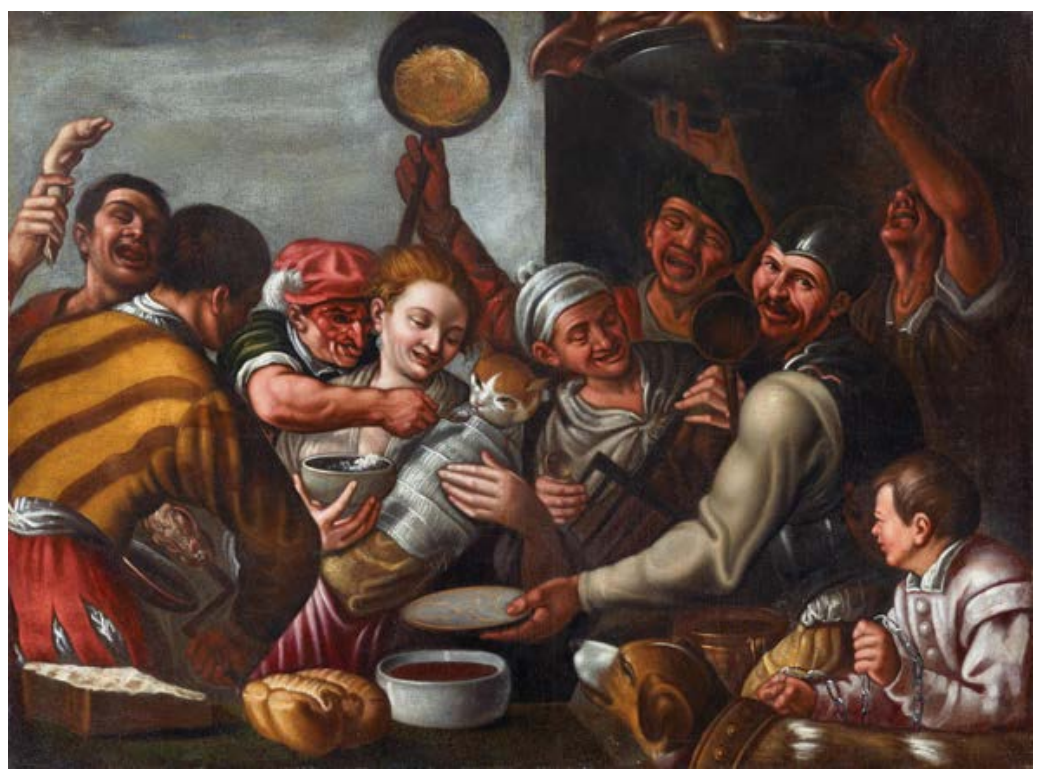

Figure 4. An example of the Carnival group, oil on canvas, $95 \times 127.5 \mathrm{~cm}$, sold at Dorotheum, Vienna, 19.12.2016, lot 66. Photo: Dorotheum.

riele Paleotti explained the orders given by the Council of Trent. The chapter Delle pitture ridicole includes his "definition" of comic painting, which proves its existence: "Sono altre pitture che chiamamo ridicole, perché muovono il riso a chi le riguarda" [Those are other pictures that we call ridiculous, because they bring up laughter in those who look at them. ${ }^{3}$

\section{Comparison}

The comparison of other closely related works meant in my study the comparison of two other painting groups, the so-called Lombard group and the Carnival group.

The Lombard group of paintings show four people-three men and a women, or two men and two women, with a cat. The woman is always holding a cat in her arms, yet the cat is not swaddled. This peculiar theme seems to have been quite popular as it was repeated with some variations at least in 14 paintings which I managed to find. The possible inventor of the subject was the fourteenth-century Milanese artist Michelino

3 G. Paleotti, Discorso intorno alle immagini sacre e profane. Trattati d'Arte del Cinquecento. Fra Manierismo e Controriforma, vol. 2 (Bari: Gius. Laterza \& Figli, 1961), 390-397. Translation by Minerva Keltanen. da Besozzo, as credited and described in an ekphrasis by Lomazzo. ${ }^{4}$ This theme had particular success in the second half of the sixteenth century in Lombardy, around the circle of Lomazzo and the Accademia della Val di Blenio. Leonardo's influence seems to have been quite evident in the figures of the Lombard group.

The Carnival group depicts a group of people joking around the swaddled cat, and I found 12 variations of this theme. The figures in the scene are in a merry mood; the central figure is a woman holding a swaddled kitten like a doll or a child, which a masked man is feeding a spoonful of white porridge. Other figures-soldiers, peasants, and buffoons-are laughing and grinning, playing a gridiron, holding a clove hitch and a pancake pan, and bringing a tray of sausages, which all are Carnival food as well. These paintings have been dated from the sixteenth century to the eighteenth century and attributed to the Flemish School, School of Naples, North Italian or Venetian School.

Serenade to a Cat series does not seem to be the clear match to the first Lombard group or of the

G. P. Lomazzo, Trattato dell'arte della pittura, scoltura, et architettura (Milan: Per Paolo Gottardo Pontio, a instantia di Pietro Tini, 1584), book VI, chap. XXXII, 359-360.

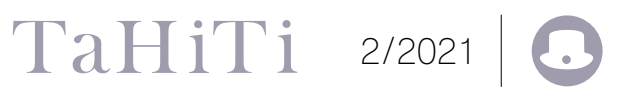


other, but the paintings have affinities with both groups. The cat seems to be regarded as the comic animal and the source of laughter in all of these groups.

The symbolism of the cat is ambiguous, based on varying cultural associations connected with changing habits. Cats were domesticated around four thousand years ago in Egypt, where they were much appreciated and actually worshipped. The cat's shifting eyes, its ability to hunt at night and play with its living prey before eating led people to associate the cat with witches and powers of darkness, even the devil incarnate. The association of dogs with men and cats with women is practically universal. Cats were also associated with sexual promiscuity, prostitutes, and lust. This association was probably based on Aristotle's belief that female cats had a libidinous nature, with which they tempted the male species into sexual intercourse. ${ }^{5}$

\section{Contextualization}

We do not know if Serenade to a Cat is an imaginary, fictive narrative or depicting a snapshot of an actual historical event that happened in the past. Yet, interpreting the Serenade to a Cat images as a historical event-showing five persons, of which the only woman is holding a cat, one man is playing a gridiron, and other man is holding a cauldron-is rather meaningless and without historical context does not give us much information.

Some of my premises in interpreting the theme is that it is linked to peasantry, folk rituals, Carnival, and theater. Furthermore, the possibility of blasphemous presentation was investigated. The peasants and the cat were common figures right from the start in early modern comic images. The peasants had connotations of being laughable, ugly, and acting foolishly, and the peasant became the most popular character in genre painting. In the French verse of the Serenade to a Cat prints, the low-class figures depicted are called foolish, thus repeating the negative views and Otherness attached to the peasants.

Now I will shortly review the results of my study.

\section{Results}

The visual evidence revealed that at the beginning of the early modern age, the relationship between man and cat was complex and multi-layered. On the one hand, depictions of the cat as a pet or scenes of domestic intimacy started to appear, but on the other hand, the cat was loaded with negative symbolism and prejudices. In visual art, the poor cat was constantly depicted as a laughing stock and object of abuse, teased by children and adults alike. Laughter in Serenade to a Cat images, in my opinion, is derisive and humiliating laughing, which is consonant with the superiority theory.

My research reveals that there is more than one plausible explanation for the theme in the timeframe of 1580-1640. The theme of Serenade to a Cat touches on several topics of the contemporary society: the misogynist attitudes, which culminated in witch-hunts; the abuse of domestic animals; the power of folk beliefs and festivals; the decline of popular culture and laughter; the class-hatred toward the peasants; the spread of vernacular theater; and derision of the classical idealizing themes.

Due to the anthropocentrism in the early modern period, animals were instrumental in human thought. With the festivities of the solstice and Carnivals, cats were easy victims and scapegoats for the evil in society, and their public killing was a kind of demonic exorcism that cleansed the community. From this perspective, we could interpret the subject matter as reflecting cat-killing rituals during such public festivities. As charivaris, faire le chat, and other carnivalesque and festive examples of cat-torturing show, abuse and 
cruelty toward animals was also considered entertaining in the early modern era.

The other explanations offered for the Serenade to a Cat theme variate from an Allegory of Five Senses to a comedy theater play or a farce, as exemplified in the Farce of the Catmaker from 1578, which has preserved in the Haarlem Chamber of Rhetorics. ${ }^{6}$ The subject could also allude to general human folly, people ridiculed and satirized for caring for their pets, even though the reason for the horrific end of the cat - which is mentioned in the verse of prints - is not so clear in this explanation. A blasphemous parody of the Holy Family seems somewhat unlikely to me, as it would have been quite a risky subject during this period. However, it could present the parody of the rite Charivari de la Chandeleur, in which Saint Joseph fed the Holy Child. The cat could be also a metaphor for lasciviousness, and it is punished, castrated, or even killed so that it would learn the manners of "civilized adults." Which one of these many possibilities is the right interpretation may be forever lost to time, no matter how much attention and time are given to research.

In studying the models for the figures depicted in the Serenade to a Cat paintings, I found possible influences from Albrecht Dürer, Cornelis Corneliszoon van Haarlem, Simon Vouet, and the School of Fontainebleau, in addition to the North Italian painting, mainly Vincenzo Campi and Bartolomeo Passerotti. In fact, influences from diverse artistic models makes it difficult to locate exactly where the Serenade to a Cat images were produced, but possibly it was not a single workshop and place. Some versions of the Serenade to

W.N.M Hüsken, W.N.M, B.A.M. Ramakers \& F.A.M. Schaars, Trou moet blijcken. Bronnenuitgave van de boeken der Haarlemse rederijkerskamer'de Pellicanisten'. De katmaecker (Leiden: DBNL, 1992), part 1, book a, http://www.dbnl.org/tekst/_tro001fams01_01/_tro001fams01_01_0012.php\#11. a Cat are of lesser quality, which possibly means that they were made in a second-rate workshop, or that the master's work was passively copied by his students for the open market. Serenade to a Cat images reveal the intensive artistic and cultural exchanges that took place in the early modern era between North Europe and Italy.

Comic paintings were acquired by collectors who were members of the elite or the wealthy middle class, and they kept their comic paintings in the living or dining rooms to inspire discussions with guests and elicit mutual laughter. The function of humorous art has been mainly interpreted by scholars as promoting moral truths or provoking its viewers to laugh and be entertained.

Finally, these marginal comic images, which were copied and disseminated for a certain period, enrich our picture of certain underlying sublimated aggressions and anxieties of societies of the past, and how laughter functioned as a therapeutic release for them. By studying the comic theme of Serenade to a Cat I have contributed to the understanding of early modern comic genre painting, and the human-animal relationship, which is illustrated here by the cat. The cat remains the constant source of humor for the paintings presented in this research, and in that sense Serenade to a Cat and similar works of art prove that the origin of "lolcats" and other images and videos of cats in humorous situations in our time is not a modern thing.

PhD Minerva Keltanen has been the head of exhibitions in The National Museum of Finland since 2014. Before, she worked as a chief curator and director at the Sinebrychoff Art Museum and as a researcher in The Finnish Glass Museum. She has also made research in the Finnish Institute of Rome, where she took part in Professor Päivi Setälä's research group with a study on the use of empresses in the state propaganda. 